\title{
Internationalising Indian Higher Education: Opportunities, Challenges and the Way Forward
}

Mr. Gautam Rajkhowa ${ }^{+}$

\section{Abstract}

This paper examines the higher education system in India together with its status regarding internationalisation, and presents the case for the higher education sector in India to embrace internationalisation.

Starting with an overview of the academic literature around the concepts of globalisation and internationalisation, and their interrelationship particularly in the context of higher education, the paper focuses on the specific issues of Indian higher education especially within the context of internationalisation. Reviewing the current landscape of the Indian higher education sector, the paper concludes that, in the context of a globally connected world, higher education in India is characterised by asymmetry in flows and unclear policies. Recommending that the internationalisation strategy focuses on the four strands of student and programme mobility; infrastructure and policy support; development of research capability; and the employment of technology as an enabler, the paper concludes that a clear approach to internationalisation would offer the potential to secure India a formidable global standing in higher education.

Keywords: Internationalisation, Cross-Border Higher Education, Internationalising Indian Higher Education, Learn in India

'Senior Lecturer in Business Management, Newman University, Birmingham UK, Email:g.rajkhowa@newman.ac.uk (C) 2017 Rajkhowa. This is an Open Access article distributed under the terms of the Creative Commons Attribution License (http://creativecommons.org/licenses/by/2.0), which permits unrestricted use, distribution, and reproduction in any medium, provided the original work is properly cited. 


\section{Introduction}

The global movement of students across borders is commonly referred to as the most visible indicator of the internationalisation of higher education. Students are moving across nations in increasing numbers, and this phenomenon is largely a feature of the growing global inter-connectedness, some commentators refer to as globalisation ${ }^{1}$ (Giddens 2000, Nye 2002, Youssef, 2014). In 2012 , the number of students studying outside their country of origin stood at 4.5 million \{Organisation for Economic Co-operation and Development (OECD), 2015\}. This figure is currently estimated to be over 5 million, which is roughly more than triple the number in 1991. By 2025, it is estimated that close to 10 million students will be studying outside their country of origin. Goddard (2011) estimates that the number of students pursuing higher education will rise to 262 million in 2025 from the 97 million in 2000; a 170 per cent expansion.

UNESCO's position paper interprets internationalisation "as one of the ways in which higher education is responding to the opportunities and challenges of globalisation. Internationalisation includes a broad range of elements such as curriculum, teaching/learning, research, institutional agreements, students/faculty mobility, development cooperation and many more" (UNESCO 2003).

The terms 'globalisation' and 'internationalisation', though closely related, and often used interchangeably, refer to two distinct phenomena (Albatch \& Knight, 2007). Globalisation, in a narrow higher education context, typically makes reference to the broad economic, technological, and scientific patterns that directly affect higher education and are largely inevitable in the contemporary world, whereas internationalisation refers to specific policies and programmes undertaken by the governments, academic systems and institutions, and even individual departments to support student or faculty exchanges, encourage collaborative research overseas, set up joint teaching programmes in other countries or myriad associated initiatives (Albatch and Knight 2007).

Maringe (2010) views globalisation as a multidimensional concept that relates to creating a world in which the social, cultural, technological, political and ideological aspects become increasingly homogenous and in which economic interdependence and growth are driven by the principles of the free market.

Knight (2004, 2006) views internationalisation at the national sector and institutional levels as the process of integrating an international, intercultural or global dimension into the purpose, functions or delivery of postsecondary education" (author's emphasis); process clearly underscoring the continuous and ongoing nature of internationalisation, integration implying that internationalisation is not something which is marginal but central and purpose clearly signalling the overall role and objectives that higher education has for a country or a region where individual institutions have specific mandates and missions.

Knight suggests that two components clearly emerge from the debate around internationalisation of higher education: internationalisation at home-those activities that help students to develop international understanding and intercultural skills that prepare students to become more active participants in a globalised environment; and internationalisation abroad, which encompasses all forms of education across borders, including circulation of students, faculty, scholars and programmes.

\footnotetext{
${ }^{1}$ Globalisation, in the wider sense, remains the subject of considerable academic and political debate, especially regarding whether it is a noun representing a given phenomenon, an adjective to describe a trend, or a verb that portrays a process.
} 
Figure 1: Two Pillars of Internationalisation: At Home and Cross-Border Education

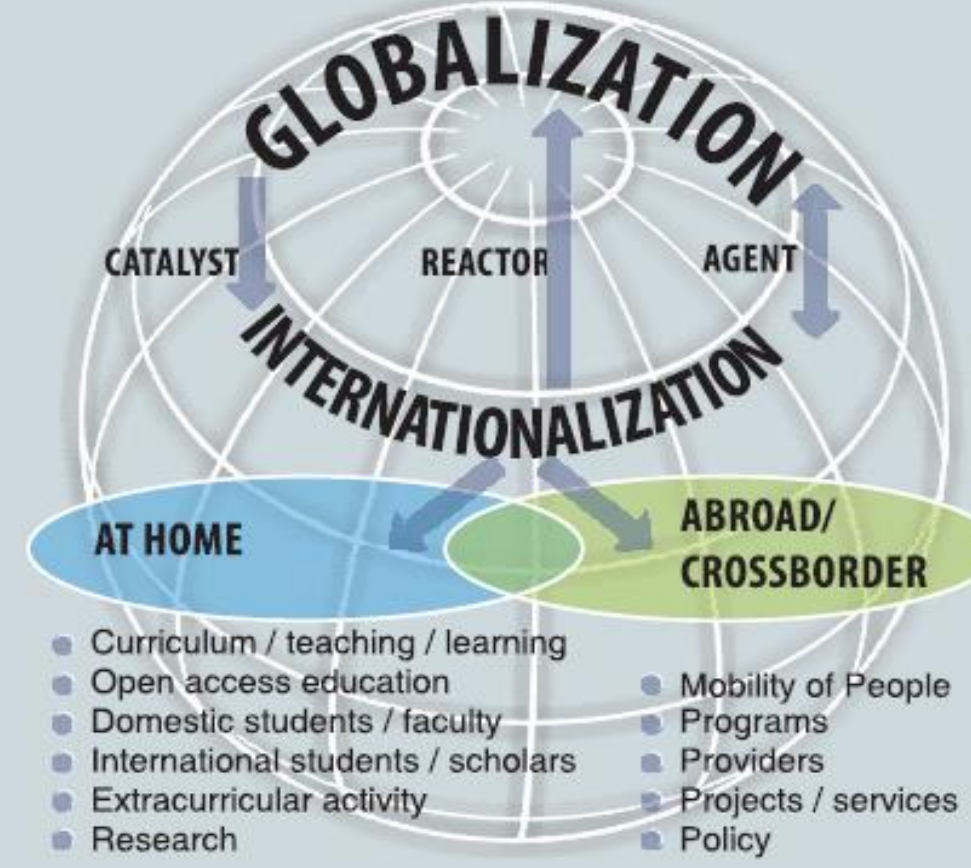

Source: Knight Jane (2014). Changing Landscape of Cross-Border Higher Education in Trends of Internationalization of Higher Education in India, Confederation of Indian Industry, November 2014

Hawawini (2016) views internationalisation as a process, which integrates a higher education institution and its key stakeholders; students and faculty into the emerging global knowledge economy. This view captures both the inward and outward aspects of internationalisation. Hawawini further suggests that the outward aspects of internationalisation would very much depend on how higher education institutions view the process of knowledge origination and dissemination in a global environment.

\section{Higher Education in India: Size, Shape and Context}

With a population nearing 1.3 billion, half of which is in the age group of 25 or below and a projection that by 2030 , India will have 140 million people in the college-going age range, India holds great potential to become a major source for world talent.

With one in four graduates in the world being a product of the Indian education system, India, already has the third largest higher education system in the world in terms of enrolment, after China and the United States. The number of students enrolled in the higher education sector (colleges and universities) in formal taught courses, including in open and distance learning provision, is estimated to be in the region of 34.2 million \{Ministry of Human Resource Development (MHRD), Government of India (GOI), 2016\}. However, the biggest challenge the country's policymakers face today is to put in place an effective system which is capable of training and educating this young population to deliver on the abovementioned 'demographic dividend'. Gross Enrolment Ratio (GER) in higher education-the number of individuals participating in higher education as a percentage of the college-age population is currently estimated at 24.3 per cent (MHRD, GOI, 2016). The government's stated aim is to achieve 30 per cent by 2020 . Various estimates indicate that to achieve this would require an additional 1,500 higher education institutions (HEls).

Modelled around the University of London, the first universities were established in 1857 by the British in Calcutta (Kolkata), Bombay (Mumbai) and Madras (Chennai). From around 20 universities and 500 colleges in 1950, the sector has grown to 760 universities and 38, 
498 colleges and 12,276 stand-alone institutions (MHRD, GOI, 2016).

\section{Table 1: Various Types of Institutions and the Corresponding Numbers} Type of Institution

Number as on

2014-15

\begin{tabular}{lc}
\hline Central University & 43 \\
\hline State Public University & 316 \\
\hline Deemed to be University & 122 \\
\hline State Private University & 185 \\
\hline Central Open University & 1 \\
\hline State Open University & 13 \\
\hline Institution of National importance & 75 \\
\hline State Private Open University & 1 \\
\hline Institutions under State Legislature Act & 5 \\
\hline Others & 3 \\
\hline Total (Universities) & $\mathbf{7 6 0}$ \\
\hline College & $\mathbf{3 8 4 9 8}$ \\
\hline Stand Alone Institutions & 3845 \\
\hline Diploma-level Technical & 431 \\
\hline PGDM & 3114 \\
\hline Diploma-level Nursing & 4730 \\
\hline Diploma-level Teacher Training & 156 \\
\hline$\quad$ Institute under Ministries & $\mathbf{1 2 2 7 6}$
\end{tabular}

Source: Ministry of Human Resource Development, Government of India (2016). Educational Statistics at a Glance

Sharma (2013) suggests that the current Indian system is the result of a complex interplay of national and state aims, plans, and execution intermingled with desires for individual and collective economic and social development and layered with concerns of equity and access. India's challenge in higher education is not just about equity and access, but also equally, it is about quality, excellence, relevance, governance, funding, encouraging diversity, and enhancing capacity. In terms of enhancing capacity, it should be noted significant progress has been made. GER has increased from 0.40 per cent in 1950-51 to 24.3 per cent in 2014-15 (MHRD, GOI 2016). However, it should be equally noted that it is in the area of relevance where significant development is required. Relevance is very much a part of quality. Whilst for students, this is the ability to secure attractive employment and the acquisition of qualifications that are recognised for further and higher studies worldwide, employers assess relevance and quality through the knowledge and skills that newly appointed graduates bring.

While the practice of delivering programmes that are specifically designed to prepare students for the workplace is gaining ground, India lags far behind in comparison to Western countries as well as other economically emerging nations, notably Brazil (Powar, 2012). In the past two decades, whilst the Indian economy has experienced a high growth in the service sector fuelled by the growth in information technology enabled services (ITeS), the Indian higher education trajectory has not taken into cognisance this exponential development and very often there is a mismatch between the skills higher education provides to graduates and the skills required by India's employers (Rajkhowa, 2013).

Industry reports supported by India's National Association of Software and Service Companies 
(Nasscom) indicate that only 25 per cent of technical graduates and 15 per cent of other graduates are considered employable in the IT and ITeS sectors. Increasingly Indian employers are spending significant resources in training and up-skilling graduates whilst in employment.

Competition for admission to India's best institutions is very intense. Only about 2 percent of those taking admission tests for the prestigious Indian Institute of Technology (IIT) and Indian Institute of Management (IIM) gain admission, and other high quality education options are needed for the many talented students who are turned away from these and other premier institutions. In addition, there are inherent capacity constraints in the system. Consequently, aspirants for quality education are seeking educational opportunities overseas. Annually approximately, 300,000 students travel overseas seeking educational opportunities. However, the problem of skills shortage continues as even after returning home from studies abroad, lack of formal systems of academic recognition between India and other countries makes it extremely difficult for such students to gain employment or set up professional practice in medicines and related fields.

\section{Indian Higher Education: Perspective to Internationalisation}

Student mobility and global exchange is not something new to India. As early as 7th century BC, Takshashila (spelt nowadays as Taxila) attracted more than 10,500 students from all over the world who studied in more than 60 subjects at this university (Tilak, 2010).

The University of Nalanda, believed to be built in the 4th century BC, finds an important place in the valuable account of India left by the Chinese traveller and scholar Hiuen Tsang, who visited India in the $7^{\text {th }}$ century A.D. (Rajkhowa, 1935). Considered to be one of the great achievements of the ancient period in the field of education, the university attracted over 10,000 scholars and students from Korea, Japan, China, Indonesia, Tibet, Persia and other parts of the globe (Rajkhowa, 1935; Tilak, 2010). In a new incarnation, Nalanda University has opened its doors close to its original location in order to capture some of the history, and establish itself as a hub of interdisciplinary research and learning for the current times (http://www.nalandauniv.edu.in/).

In the last two decades, however, the dominant theme in the internationalisation strand has been largely outward mobility. Various studies conducted by the Institute of International Education (IIE-Project Atlas), USA Association of Indian Universities (AIU) and the Ministry of HRD, Government of India (MHRD , GOI) on the mobility of students from and to India indicate that the flow of students has predominantly been outward bound; the number of Indian students going overseas every year is estimated to be in the region of 300,000 , whereas the inflow of overseas students into India is 42,293 . The number of international students enrolled, as a percentage of the total number of students enrolled in higher education is miniscule when compared to the $21.4 \%$ enrolled in Australia and the $19.5 \%$ in the UK. China, who is a late entry in attracting international students, has approximately 330,000 international students with a target of 500,000 by 2020 . Singapore and Malaysia have developed into strong international education destinations in the South East Asia region. Singapore, with approximately $720 \mathrm{sq}$. $\mathrm{km}$ in land area, attracts close to 90,000 international students; and Malaysia attracts over 150,000 international students annually.

India's predominant position as a provider of quality higher education in the developing economies of the South Asian region is well documented. Asher (2007) notes in particular the role of Indian management and engineering institutions in providing skills training to populations in parts of Asia and Africa and in helping develop globally competitive workforce. India's ability to offer higher education in English at a fraction of the cost of the established Western providers, combined with its physical proximity to regions that are teeming with higher education aspirants in the 
South Asian region, further strengthens the country's position as a host provider for higher education.

Whilst there has been much debate on reforms in higher education in India, what is however required is systemic thinking on how reforms could contribute to providing a specific focus towards internationalisation. Such reforms would also help towards achieving a balance with regard to net outflow and inflow of valuable foreign exchange resources in this sector.

\section{The Way Forward}

From an Indian perspective, the focus should be on how global resources can be utilised to build capacity, increase access, enhance quality and encourage diversity, and less on the commercial opportunities associated with the fast growing global market in higher education. The current initiative of the Government of India in framing a New Education Policy is a step in this direction.

'Empowering India through quality education' as the underlying theme, the report (National Policy on Education 2016, MHRD, GOI) provides an overarching commentary and specific recommendations for the education sector in India from school education to higher education addressing issues of regulation, governance, and reform required for strengthening national level institutions. Notably, in the specific area of internationalising higher education, the committee recognises the significant imbalance in the area of student mobility and makes the following recommendations:

Selected foreign universities from the top 200 in the world should be encouraged to establish their presence in India through collaboration with Indian universities. It should be made possible for a foreign university to be in a position to offer its own degree to the Indian students studying in India, such that these degrees should be valid also in the counbtry of origin.
Encouragement should be given to 'high quality' foreign universities and educational institutions to collaborate with Indian partners and establish an Indian presence. Appropriate enabling legislation, as required, may be enacted (pp 207, 208)

This, the report urges should be placed within the broad opportunity to 'globalise' Indian higher education without compromising the basic tenets of access, equity and quality of education. These commitments towards internationalisation of higher education and the rationale for the same, demonstrates India's stand on the subject. The Indian Prime Minister Mr. Narendra Damodar Modi who on April 23, 2015 tweeted further reflects this in a tweet:

India can meet skilled manpower of the entire world.... We need to assess our capabilities in the global context (https://twitter.com/narendramodi/stat us/591252445092646912)

The Prime Minister's tweet provides an indication of the importance the government accords to internationalisation of higher education in the global context of providing educated and skilled manpower.

There are both opportunities and challenges in internationalising higher education. Enhanced capacity, greater access for students, development of joint curriculum, greater diversity of programmes, exposure to a variety of teaching and learning methods, growing comparability of qualifications, exposure to established systems of education administration and management, less brain drain of gifted and bright students to foreign institutions, fusion of cultures, exchange of research ideas and enhancement of research capacity, establishment of multinational and cross-disciplinary team and generation of new academic environments are some of the opportunities that internationalisation offers.

The challenges and risks concern the quality of provision, high fees leading to an elitist provision, inequality of access leading to a 
two-tier system, which is inconsistent with the equity and access drivers of the nation's higher education policy.

To be considered a major player in the global higher education arena, higher education in India needs a comprehensive internationalisation strategy both at the national level as well as at the institutional level.

Developing a strong international perspective would require emphasis and focus on the following areas:

- Student and programme mobility

- Infrastructure and policy support

- Development of research capability

- Use of technology as an enabler

\section{Student and Programme Mobility}

One of the fundamental drivers to internationalising higher education in India will be the ability of Indian universities and colleges to attract foreign faculty and students to India. This can only happen when a clear framework mapping curriculum with international standards and an internationally recognised credit transfer system would enable Indian higher education institutions to collaborate with foreign providers for joint programmes, dual degrees, student and faculty exchange programmes, facilitating greater student mobility across systems.

Such partnerships would not only help build capacity in meeting student demand but would also help develop greater awareness of global issues to both overseas students and Indian students who cannot be internationally mobile, develop inter-cultural fluency, thus, promoting 'internationalisation at home'. Students, who have exposure to an international educational experience, even in small measure, enjoy more employability in the global job market.

As Albtach (1989: 126) highlighted almost a quarter century ago, they are "one of the most important elements of the international knowledge system. In many ways, they are the centre of the system, they are the carriers of knowledge across borders.... They are the embodiment of the cosmopolitan culture.... Foreign students and scholars are one of the most visible and important parts of the worldwide exchange of knowledge"

International students will enhance the diversity of Indian campuses, and over the years, international students would help enhance India's visibility and presence in the world's socio-cultural and education spaces, notwithstanding the tremendous opportunity for soft diplomacy that goes with overseas students returning home from India. The notion of soft power and its application to the Indian context reinforces the case about strengthening India's brand standing, es pecially in the South Asian region, as a provider of cross-border higher education and leader in knowledge creation and dissemination.

\section{Infrastructure and Policy Support}

Whilst the broad position of the National government is to encourage foreign engagement, what is absolutely essential is a clear and transparent policy with regard to institutional partnerships between Indian and foreign institutions. These partnerships would not only help build capacity in meeting student demand, build research capability through mapping of global networks for research and employment, but also provide an opportunity to fine tune the country's higher education accreditation and approval systems through benchmarking and aligning, the quality assurance systems to international standards. Indian institutions should also be allowed to hire international faculty on long-term contracts and to permanent positions.

Creating 'education hubs' in strategic geographical locations clearly coordinated with the government's current drive to establish 'Smart Cities' (http://smartcities.gov.in/) should be seen both from capacity building and economic perspectives. Allowing reputable overseas institutions to establish a presence in India through joint initiatives in curriculum design and delivery, research and scholarly activities and establishing a physical presence, would not only help build capacity, but also reduce the imbalance in students mobility 
whilst at the same time, bringing in significant export earnings.

Another aspect of internationalisation is to put in place clear policies that encourage Indian institutions to establish a presence overseas, either by establishing their own campus or in strategic partnership with a local institution.

\section{Development of Research Capability}

Partnerships with international HEls have boundless potential to infuse the oft-repeated 'culture of research' the very pinnacle of higher education ranking. Whilst many Indian institutions today are engaged in cutting-edge research, the failure of Indian universities to make it regularly to the top 200 global list is partly due to weak international links. The Indian higher education landscape has often been described as one which is marked by islands of excellence in a sea of mediocrity enmeshed in a culture of regulation subject to the whims of politicians, and subsequently, unable to plan for their own future (Albtach and Jayaram, 2008; Sharma, 2013). Weak research capacity and international collaborations have often been cited as one of the reasons why some of the brightest and best Indian students migrate overseas for research studies.

To leverage the demographic dividend, sustain economic development, and gain competitiveness in the global market, the higher education sector would need to significantly enhance research capabilities. The emphasis must be to encourage domestic research institutions on building research capacity from the ground up and not merely importing research infrastructure and resources. India has to assert its rightful place in such collaborative arrangements and focus on developing collaborative ventures with clear mandates to develop research potential.

In the new millennium, as India becomes more globally networked, new partnership models involving students and staff mobility, as well as joint academic and research activities are being pursued. Initiatives such as the UK India Education Research Initiative (UKIERI), the
Singh Obama 21st Century Knowledge Initiative between India and the US and more recently, through the Global Initiative for Academic Networks (GIAN) are a few steps in the right direction. Only when Indian academics and researchers are collaborating and working with the best in the world, will Indian HEls become more internationally productive and relevant.

\section{Use of Technology as an Enabler}

India has very specific skills and knowledge in information communication technology, which it should leverage on a global scale to develop world-class platforms to provide open and distance learning programmes. SWAYAM (Study Web of Active-Learning for Young Aspiring Minds), the MOOCs announced by the government should be seen as a platform to reach out to a wider international audience. The 'Digital India' initiative should be well integrated with the education network to develop a strong 'Learn in India' platform to complement 'Make in India' (a platform launched by India's Prime Minister on 25 September 2014 with the mission 'Manufacture in India and sell the products worldwide').

To build capacity and raise quality standards, India needs educational institutions that are globally networked. Just as India has benefitted from liberalising her economy and opening it to the world, the higher education sector too would benefit from strong international partnerships. India offers a multitude of opportunities to international higher education institutions and the global student population. Indian organisations in the corporate, public and social sectors offer exciting and innovative opportunities for learning and work experience. 'Mangalyaan' (Mars Craft), India's mission to Mars, which began orbiting in September 2014, is a fitting testimony of the type of opportunities that India offers to the world.

From an Indian perspective, the focus however should be on how technology can be leveraged to pool global resources to increase access, enhance quality, and encourage diversity and less on the commercial opportunities associated with the rapidly growing global market in higher education. 


\section{Concluding Remarks}

India has a lot to gain from opening up its higher education sector, just as it had done with the liberalisation of economy in the mid1990s.

As Wildavsky (2010:197), has observed: “[j]ust as constraining traditional forms of trade hurts consumers and stymies economic creativity, closing doors to free flow of people and ideas thwarts knowledge generation, which is the life blood of successful economies."

In the context of a globally connected world, higher education in India is characterised by asymmetry in flows and unclear policies. What Indian higher education requires is a set of clear and transparent policies that would enable partnerships with leading global institutions in the areas of curriculum development, research, establishment of collaborative learning programmes and awards. The emphasis of any such policy should be on governance and establishing governance structures rather than merely regulation. Like Singapore, Dubai, Malaysia and now China, India has the potential and should position itself as a centre for quality higher education. There is also a clear opportunity to establish a regional framework to harmonise systems of higher education for the Association of Southeast Asian Nations (ASEAN) and BRICS (Brazil, Russia, India, China and South Africa) countries similar to the Bologna process, a collective effort between European nations to ensure compatibility in the standards and quality of higher education qualifications, mutual recognition of qualifications, transparency of systems and ensuring the mobility of both students and staff across higher education institutions in Europe. India should take a leadership role in initiating this.

Internationalisation needs strategic international cooperation and planning both at systemic and institutional levels to create an environment, which address the issues of student mobility, enhanced capacity and establishing international competitiveness, while at the same time, being consistent with the equity, access and quality drivers of the nation's higher education policy.

India must clearly define its higher education policy objectives in order to benefit from increased global student mobility and growing internationalisation.

It is time India's higher education policy reflected on how best to benefit from the 'demographic dividend' and leverage on internationalisation. 'Make in India', 'Digital India' and the 'Smart Cities' initiatives should all be aligned with a clear, transparent and forward thinking higher education policy. This would secure India a formidable global standing in higher education.

\section{References}

Albtach, P.G. (1989). The New Internationalism: Foreign Students and Scholars, Studies in Higher Education 14(2), 125-136

Albtach, P.G., \& Knight, Jane (2007). The Internationalisation of Higher Education: Motivations and Realities, Journal of Studies in International Education, 11(374), 290-305

Albatch, P.G. (2009). The Giants Awake: Higher Education Systems in China and India", Economic and Political Weekly, 44(23), 39-51

Agarwal, Pawan (2012). A Half-Century of Indian Higher Education: Essays by Philip G Altbach, New Delhi: SAGE Publications.

Altbach, P., \& Jayaram, N. (2008). Towards Creation of World Class Universities. The Hindu, 23 October.

Giddens, A. (2000). Runaway World: How Globalization Is Reshaping Our Lives. New York: Routledge

Goddard, B. (2011). Future Perspectives: Horizon 2025. In Davis, D., \& Mackintosh, B. (eds). Making a Difference: Australian International Education. New South Publishing, Sydney, pp. 396-414. 
Hawawini, G. (2016). Future of Outward Higher Education Internationalisation, World University News, Issue No 447 February 17, 2017.

Knight, Jane (2004). Internationalisation Remodelled: Definition, Approaches, and Rationales, Journal of Studies in International Education, 8(1), 5-31

Knight, Jane. (2005). Commercial Cross Border Education: Implications for Financing Higher Education, Higher Education in the World, 2006: The Financing of Universities, Palgrave Macmillan, Basingstoke, 103-112.

Knight, Jane (2006). Internationalisation of HE: New Directions, New Challenges: The 2005 IUA Global Survey Report. Paris: International Association of Universities

Knight, Jane (2008). Higher Education in Turmoil: The Changing World of Internationalization. Rotterdam, Netherlands: Sense.

Knight, J. (2012). Internationalisation: 'Three Generations of Cross Border Higher Education', Paper Presented at India International Centre, New Delhi, India.

Maringe, F. (2010). The Meanings of Globalization and Internationalization in HE: Findings from a World Survey. In Maringe, F., \& Foskett, N. (eds) Globalization and Internationalization in Higher Education: Theoretical, Strategic and Management Perspectives. Continuum International Publishing Group, London, pp. 17-34.

MHRD, GOI (2016). Education Statistics at a Glance, available at http://mhrd.gov.in/sites/upload_files/m hrd/files/statistics/ESG2016_0.pdf [accessed on 12 May 2017]

MHRD, GOI (2016). National Policy on Education 2016: Report of the Committee for Evolution of the New Education Policy, Government of India $30 / 04 / 2016$
Nye, Joseph (2002). Globalism versus Globalization: What Are The Different Spheres of Globalism - and How Are They Affected by Globalization?" available at https://www.theglobalist.com/globalis m-versus-globalization/ [accessed on 21May 2017]

OECD (2015). Education at a Glance: OECD Indicators, available at http://www.keepeek.com/Digital-AssetManagement/oecd/education/educatio n-at-a-glance-2015_eag-2015en\#.WSafAGjyuUk [accessed on 12 May 2017]

Powar, K. B. (2012). Expanding Domains in Indian Higher Education. New Delhi, India: Association of Indian Universities Publications, New Delhi

Project Atlas (2013), available at: www.iie.org/en/Services/ProjectAtlas/India/Indias-Students Overseas [accessed on 15 May 2017]

Rajkhowa, S.C. (1935) Ancient European and Indian Universities. In Sharma and Sharma (eds) Encyclopaedia of Higher Education: The Indian Perspective (Vol. 1, 1-6) Mittal Publication, New Delhi, 2005

Rajkhowa, G. (2013). Cross Border Higher Education in India: Challenges and Opportunities, International Journal of Organisational Analysis, 21(3), 471-484

Sharma, K. (2013), Sixty Years of the University Grants Commission, Establishment, Growth and Evolution. UGC, New Delhi

Tilak, J.B.G. (2010). Universities: An Endangered Species? Journal of the World Universities Forum, 3(2), 109-128.

UNESCO (2003). Education in a Multilingual World. UNESCO Education Position Paper, available at http://unesdoc.unesco.org/images/001 2/001297/129728e.pdf [accessed on 24 May 2017] 
Wildavsky, B. (2010). The Great Brain Race: How Global Universities are Reshaping the World, Princeton University Press, Princeton, NJ.

Youssef, Leila (2014).Globalisation and Higher Education: from Within-Border to Cross
Border, available at:

http://www.tandfonline.com/doi/abs/1 0.1080/02680513.2014.932686

[accessed on 21 May 2107]. 